\title{
Assessment the Strength of Column and Beam at Religious Building Structure by Using Non- Destructive Test
}

\author{
Nor Azizah Adnan ${ }^{1, *}$ \\ ${ }^{1}$ Universiti Teknologi Malaysia, Johor Bahru, 81310 Johor, Malaysia
}

\begin{abstract}
The mosque is a sacred place for worship for Muslims. To this date, the traditional mosque needs to be conserved and preserved wood for aesthetic value. Nowadays, most of the mosque materials have a combination of other materials such as concrete, wood and glass. In order to maintain its fit-for-purpose status, non-destructive tests (NDTs) are recommended to be done periodically to identify hidden deteriorations for planning maintenance and repair works without damaging the structure itself. This paper presents two NDTs - Ultrasonic Pulse Velocity tool (PUNDIT) and Schmidt rebound hammer test - done on 38 concrete columns and 29 ground beams of Masjid Kampung Ulu Semerah, Batu Pahat. Recorded readings have shown that most beams and columns had moderate or weak strength. As such, remedial action should be taken to uphold the mosque's structural integrity.
\end{abstract}

\section{Introduction}

Referring to Jabatan Agama Islam Johor (JAIJ) and Jabatan Kemajuan Islam Malaysia (JAKIM), Johor has more than eight hundred mosques registered as center perform Friday prayers. Number of one hundred and eighty eight mosques registered as a mosque Friday in Batu Pahat and listed as the highest area in Malaysia peninsular. The geographical this area is located at the west and known for peat soil that is classified into a problematic with high compressibility and low strength. The problem that's need to be faced is about the peat soil sediment. Ideally, construction on peat soil should be avoided, if not, assessments ought to be done for the purpose aforementioned. Assessment of this study is to identify the strength level of column structure based on the results of non-destructive testing (NDT) as preliminary cracks practise. Research on the concrete structure on a mosque is too limited and less attention given. This study took the opportunity to test the ability of concrete to the place of worship that is visited by many people in a certain period. The structural strength of the building provides protection, safety and comfort to its occupants. The stability and strength of a structure depends on the condition of the foundation and underlying soil layers. To ensure that the structure is fit for purpose, tests have to be conducted periodically to safeguard its structural integrity. This is particularly true for structures built on peat soil, which is an organic soil that has high compressibility and low strength.

\footnotetext{
*Corresponding author: che.nor8253@gmail.com
} 


\section{Ultrasonic pulse velocity and rebound hammer}

Two types of tests can be done to investigate its structural integrity status, namely Destructive Testing (DT) and Non-Destructive Testing (NDT). J. Helal [1] describe that the tests category in DNT are: (1) Test Hammers Reflection (2) Test UPV (3) The method of penetration resistance (4) Drop resistance method (5) The method of resistance out (6) Methods of test maturity (7) Method absorption test and (8) The method of reinforcement corrosion. All kinds of methods have been based on suitability and testing requirements. The choice of method should be done in order to get the required data reading. A case to note is a series of Table 1 shows findings of previous studies that using NDTs.

Table 1. NDT studies on concrete

\begin{tabular}{|c|c|c|}
\hline Name, Year & Scope Studies & Tools \\
\hline $\begin{array}{l}\text { Masenwat [2] } \\
\text { NDT (Non } \\
\text { Destructive Testing) } \\
\text { in Civil Engineering: } \\
\text { Structural Integrity of } \\
\text { Concrete Inspection } \\
\text { Project }\end{array}$ & $\begin{array}{l}\text { To identify the performance of a concrete } \\
\text { structure aged } 20 \text { years old included visual } \\
\text { inspection, concrete cover meter, half-cell } \\
\text { potential, reflection hammer, and UPV. Also } \\
\text { carried out the concrete coring, testing } \\
\text { carbonation and chloride test. These tests were } \\
\text { conducted to get the current reinforcement } \\
\text { corrosion rate, the compressive strength of } \\
\text { concrete, and the reinforcement position. }\end{array}$ & $\begin{array}{l}\text { 1. Ultrasonic Pulse } \\
\text { Velocity } \\
\text { (UPV/PUNDIT) } \\
\text { 2. Half Cell Potential } \\
\text { 3. Rebound Hammer } \\
\text { Test }\end{array}$ \\
\hline $\begin{array}{l}\text { I. Lawson [3] } \\
\text { Non-Destructive } \\
\text { Evaluation of } \\
\text { Concrete using } \\
\text { Ultrasonic Pulse } \\
\text { Velocity }\end{array}$ & $\begin{array}{l}\text { To investigate the relationship between UPV and } \\
\text { the compressive strength of concrete test } \\
\text { conducted at the age of } 2,7,15 \text { and } 28 \text { days. The } \\
\text { UPV and the compressive strength of concrete } \\
\text { increases with growth rates at early ages. The } \\
\text { UPV results can be determined the uniformity of } \\
\text { concrete, detect cracking and voids in concrete, } \\
\text { control the quality of concrete and concrete, } \\
\text { detect the condition and deterioration of concrete, } \\
\text { detect the depth of a surface crack also, determine } \\
\text { the strength. }\end{array}$ & 1. PUNDIT \\
\hline $\begin{array}{l}\text { Zia [4] } \\
\text { Application Of Non } \\
\text { Destructive Test For } \\
\text { Structure } \\
\text { Evaluation }\end{array}$ & $\begin{array}{l}\text { Visual inspection had found that the effects of } \\
\text { fragmentation and significant corrosion on the } \\
\text { surface of the concrete. Decision modeling found } \\
\text { that the load applied to the structure is heavier } \\
\text { than designed. This causes excessive load-bearing } \\
\text { structures. In addition, it was found that the steel } \\
\text { reinforcement in the concrete having corrosion } \\
\text { due to ingress of water into the concrete. The } \\
\text { results obtained to determine the appropriate } \\
\text { maintenance measures against the structure. }\end{array}$ & $\begin{array}{l}\text { 1. PUNDIT } \\
\text { 2. Rebound Hammer } \\
\text { Test }\end{array}$ \\
\hline $\begin{array}{l}\text { Pauzi [5] } \\
\text { Non destructive } \\
\text { Testing (NDT) of } \\
\text { concrete containing } \\
\text { hematite }\end{array}$ & $\begin{array}{l}\text { Non-destructive ultrasonic and rebound hammer } \\
\text { measurements on concrete containing hematite. } \\
\text { Rebound Hammer Test show high strength and } \\
\text { high density concrete. Pulse velocity but also } \\
\text { increase the strength increases when the power is } \\
\text { increased again to a constant velocity and } \\
\text { purpose to measure the elastic properties of the } \\
\text { material and have an affinity with the durability } \\
\text { of the material. Recovery pulse velocity should } \\
\text { be increased in order to produce good quality } \\
\text { rebound. }\end{array}$ & $\begin{array}{l}\text { 1. PUNDIT } \\
\text { 2. Rebound Hammer } \\
\text { Test }\end{array}$ \\
\hline
\end{tabular}


This study utilized the NDT method by using Portable Ultrasonic Non-Destructive Digital Indicating Tester (PUNDIT) and Schmidt Rebound Hammer, which is widely used for building conservation works because it can easily detect hidden defects, does not damage important historical structures and the cost effective. Non-destructive testing is a popular method often used in older buildings or historic buildings to determine the strength of the building structure [6]. The published literature has an extensive library of NDT studies done on historical buildings. NDT purpose is to measure the compressive strength of concrete without damaging the original structure surface and value/reading meter referred on the graph to get an estimate compressive strength. The advantage of this test does not cause any damage to the valuable building while giving due engineering data on the current performance or structural integrity status of the building [7].

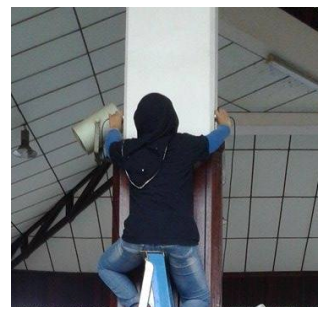

Fig. 1. Through transmission (direct)

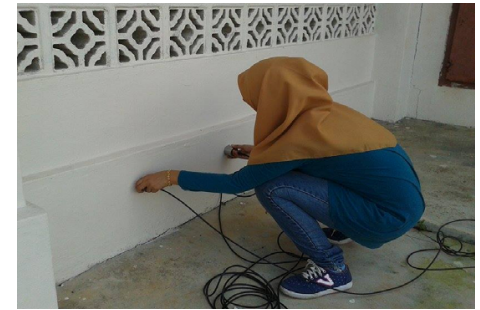

Fig. 2. Diffuse/Scattering or Surface Transmission (indirect)

Table 2. Classification quality of concrete based on the velocity PUNDIT test

\begin{tabular}{|c|c|}
\hline Velocity $\mathbf{~} \mathbf{~ 1 0}^{\mathbf{3}} \mathbf{~ m} / \mathbf{s}$ & Quality of Concrete \\
\hline$>4.6$ & Excellent \\
\hline $3.6-4.6$ & Good \\
\hline $3.0-3.6$ & Impugn \\
\hline $2.1-3.0$ & Poor \\
\hline$<2.1$ & Very poor \\
\hline
\end{tabular}

The PUNDIT method uses electrical waves to create a pulse wave that passes through structures in various velocities depending on the concrete strength and size. The transmission transducer has three types of transmission - direct, semi-direct and indirect transmission (Fig. $1 \&$ 2). Direct transmission is the most recommended since it gives the most accurate readings. As for the rebound hammer, it measures the concrete quality through the resulting reflection from the surface of the concrete. The energy absorbed by the hammer recovery allows multiple reflections, and this can be used as a marker to determine the structural strength of concrete. With the reliable readings given by both PUNDIT and Schmidt rebound hammer, appropriate maintenance and repair works can be scheduled and executed to safeguard the structural integrity of the mosque.

The Schmidt Rebound Hammer, should be 12 times [8] the beat (Fig. 3) and hummer head pressed on the concrete surface until the mass spring mass so that the plunger is released and leaves the effect of pressure on the concrete surface (Fig. $4 \& 5$ ) and readings shows on slide indicator (Fig. 6) and get the average before rebounding numbers refer to the reference graph (Table 1). 


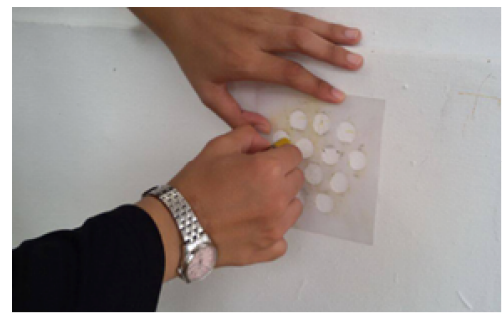

Fig. 3. Points area for rebound beat

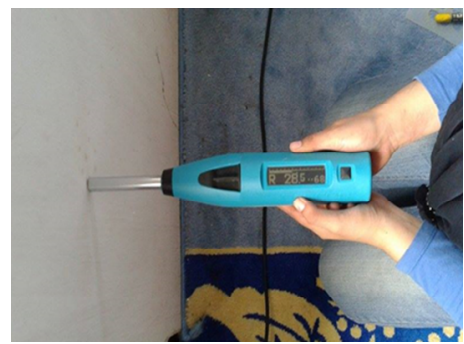

Fig. 5. Hummer head pressed on the wall or concrete surface

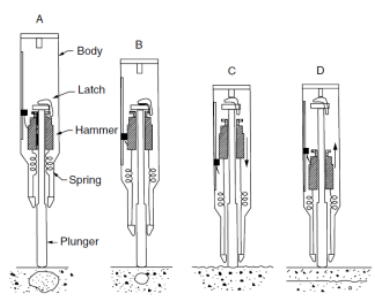

Fig. 4. Standard procedure and guideline

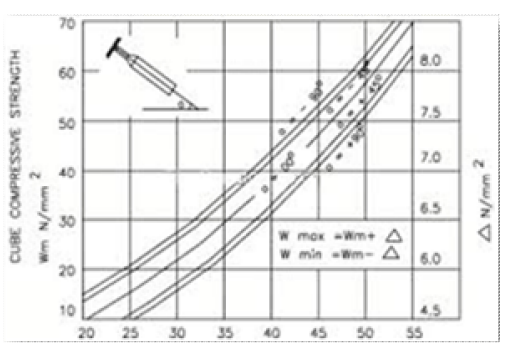

Fig. 6. Graph Strength of Concrete Vs Rebound Number (Yusof, 1995)

Table 3. Concrete quality of Schmidt Rebound Hammer (Hakim, 2002)

\begin{tabular}{|c|c|}
\hline Rebound Number Average & Quality of Concrete \\
\hline$>40$ & Good \\
\hline $30-40$ & Moderate \\
\hline $20-30$ & Poor \\
\hline$<20$ & Very Poor \\
\hline
\end{tabular}

\section{Methodology}

Case study on religious building (mosque) was conduct at Kampung Ulu Semerah, Mukim Air Hitam, Muar, Johore are through site visits, observations, measurement, interviews local committee and perform DNT on structural columns and ground beams of the mosque structure. The purpose of site visit and observation is to know and obtain information relating to the assessment that related to the environment and the strength of the mosque.

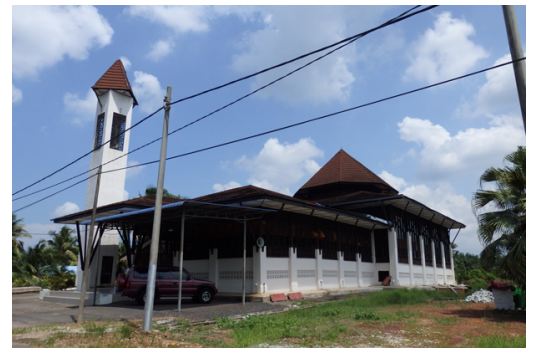

Fig. 7. Mosque architectural design

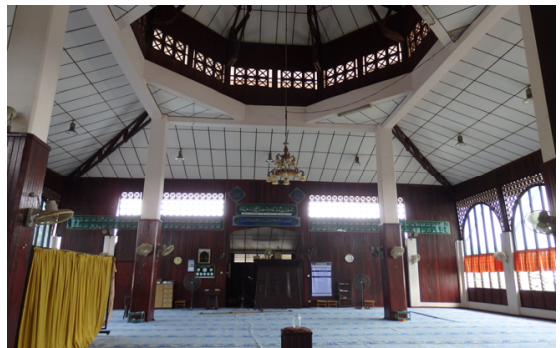

Fig. 8. Interior of the prayer hall 
Formally name as Haji Mohammed Mosque was inaugurated in 1999 (Fig. 7 and 8) and geographically stand on soft/peat soil status and the construction costs funded by individuals as donations, but after 5 years of use have shown estranged on joint between pillar-wall and wall-floor than wood strip tenuous effect (Fig. 8). Initial investigations into the mosque found the strength to be confronted the deterioration of columns and beams may affect by soil structure. Observation found that there are several 'tenuous monitor' mounted as regular monitoring for connections is made by other parties. The tenuous between connection timber walls and concrete columns are clearly visible (Fig. 9 and 10). Although the mosque was built in a decade, until now the villagers still use for prayers and perform specific events. However, after a few years there are problems in terms of stability and durability of concrete structures. Raises concerns on safety and security to residents according stability of the mosque.

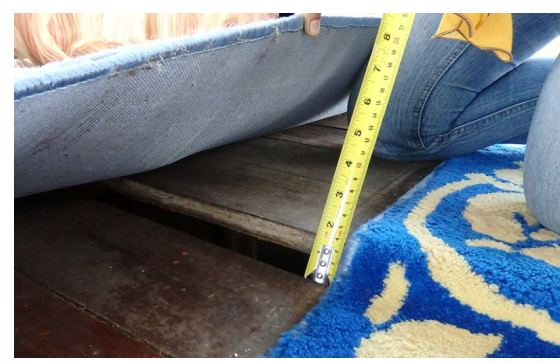

Fig. 9. Timber floor condition

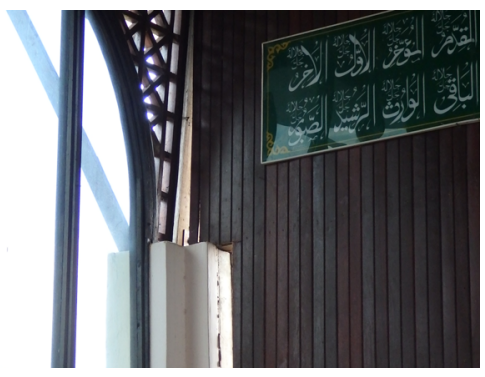

Fig. 10. Gap between wall and concrete column

Mosque architectural where combined with various materials such timber, concrete, class and metal. Internal space arrangement include $18 \mathrm{~m} \times 18 \mathrm{~m}$ of main prayer hall, $15 \mathrm{~m} \times$ $15 \mathrm{~m}$ include veranda, teaching and meeting area, $3 \mathrm{~m} \times 2.5 \mathrm{~m}$ of mihrab and $5 \mathrm{~m} \times 2.5 \mathrm{~m}$ of 2 rooms. This mosque was built with four main columns with $10 \mathrm{~m}$ heights $(0.5 \mathrm{~m} \times 0.5 \mathrm{~cm})$ from ground level at centre of prayer hall as suku guru to support octagonal concrete roof beam of the mosque roof. The suspended floor had assembled with timber stripe on timber floor beam as usually as Malay house concept while that beam is supported by rows of concrete columns with $2 \mathrm{~m}$ height raised from ground without concrete transverse beams ties. In addition, the brick wall with $3 \mathrm{~m}$ height stand and tied to $0.58 \mathrm{~m} \times 0.38 \mathrm{~m} \times 6 \mathrm{~m}$ height columns are located around the prayer hall, also tied to $1 \mathrm{~m}$ height timber panel and $1.1 \mathrm{~m}$ louvered glass windows. The distance between columns to columns is $3 \mathrm{~m}$ that forming the square of internal space. On top of louvered glass windows have $8 \mathrm{~cm}$ height timber lintel that tied to glass panel with timber frame and fixed to timber lattice panels or ventilation panel (sisip angin) purpose for obtain natural lighting and air ventilation. Although the mosque full designed with glass windows and timber panels but at high-level up to $6 \mathrm{~m}$ there is no threshold or lintel crossing the walls and more load along the walls then ties tenuous from the columns.

Mosque was measured by regular measuring tape then drawn by AutoCAD to form the layout floor plan. Table 2 shows the layout plan and points position of ground beams; B1B29 and columns; C1-C38 (Fig. 11). This NDT took about four hours to complete with three readings taken at each location were performed on 29 beams and 38 concrete columns of the mosque. There are four (4) different size for concrete columns which is $0.50 \mathrm{~m} \mathrm{X}$ $0.5 \mathrm{~m}, 0.58 \mathrm{~m} \times 0.38 \mathrm{~m}, 0.40 \mathrm{~m} \times 0.40 \mathrm{~m}, 0.51 \mathrm{~m} \times 0.51 \mathrm{~m}$ and $0.35 \mathrm{~m} \times 0.58 \mathrm{~m}$ shown in Table 4. 
Table 4. Type of columns

\begin{tabular}{|c|c|}
\hline Size & Code \\
\hline $0.50 \mathrm{~m} \times 0.5 \mathrm{~m}$ & $\mathrm{C} 1, \mathrm{C} 2, \mathrm{C} 3, \mathrm{C} 4$ \\
\hline $0.51 \mathrm{~m} \times 0.51 \mathrm{~m}$ & $\mathrm{C} 5, \mathrm{C} 6, \mathrm{C} 15, \mathrm{C} 16, \mathrm{C} 17, \mathrm{C} 18, \mathrm{C} 19, \mathrm{C} 20$ \\
\hline $0.58 \mathrm{~m} \times 0.38 \mathrm{~m}$ & $\mathrm{C} 7, \mathrm{C} 8, \mathrm{C} 9, \mathrm{C} 10, \mathrm{C} 21, \mathrm{C} 22, \mathrm{C} 23, \mathrm{C} 24, \mathrm{C} 25$ \\
\hline $0.40 \mathrm{~m} \mathrm{X} \mathrm{0.40m}$ & $\mathrm{C} 11, \mathrm{C} 12, \mathrm{C} 13, \mathrm{C} 14$ \\
\hline $0.35 \mathrm{~m} \times 0.58 \mathrm{~m}$ & $\mathrm{C} 26, \mathrm{C} 27, \mathrm{C} 28, \mathrm{C} 29, \mathrm{C} 30, \mathrm{C} 31, \mathrm{C} 32$ \\
\hline North columns $0.26 \mathrm{~m}$ & $\mathrm{C} 33, \mathrm{C} 34, \mathrm{C} 35, \mathrm{C} 36, \mathrm{C} 37, \mathrm{C} 38$ \\
\hline
\end{tabular}

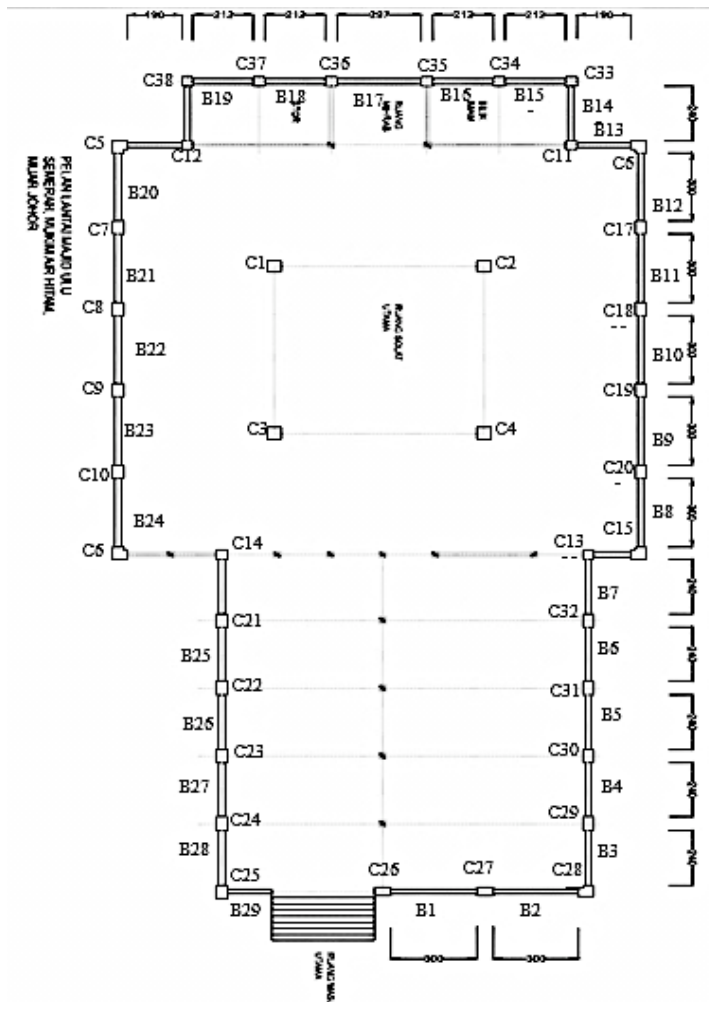

Fig. 11. Location of DNT points at mosque layout plan.

\section{Results and discussions}

Fig. 12 shows the reading of the results of tests PUNDIT to 38 columns appearing in Masjid Haji Muhamad. The columns position was tested using the method of direct delivery. Columns that have the highest reading speed is column C35 which is $4067 \mathrm{~m} / \mathrm{s}$, followed by the second highest column is C20, and C38 is the third highest with velocity $3840 \mathrm{~m} / \mathrm{s}$ and $3836 \mathrm{~m} / \mathrm{s}$ respectively. As for the velocity in the range of $3800 \mathrm{~m} / \mathrm{s}$ to $3000 \mathrm{~m} / \mathrm{s}$ is the column C36, C37, C8, C34, C30, C9 and C12. Followed with a velocity in the range of between $2900 \mathrm{~m} / \mathrm{s}$ to $2500 \mathrm{~m} / \mathrm{s}$ is the column C32, C7, C15, C10, C29, C16, C33, C14 and C13. Next to the velocity with values between $2499 \mathrm{~m} / \mathrm{s}$ to $2000 \mathrm{~m} / \mathrm{s}$ is the column C27, C23, C18, C31, C24, C3 and C21. For columns that have the velocity of $1990 \mathrm{~m} / \mathrm{s}$ to $1000 \mathrm{~m} / \mathrm{s}$ is the column C17, C6, C1, C19, C25, C4, C5, C26, C28, C2 and C22. The very low velocity which is less than $1000 \mathrm{~m} / \mathrm{s}$ is column C11 by $692 \mathrm{~m} / \mathrm{s}$. 


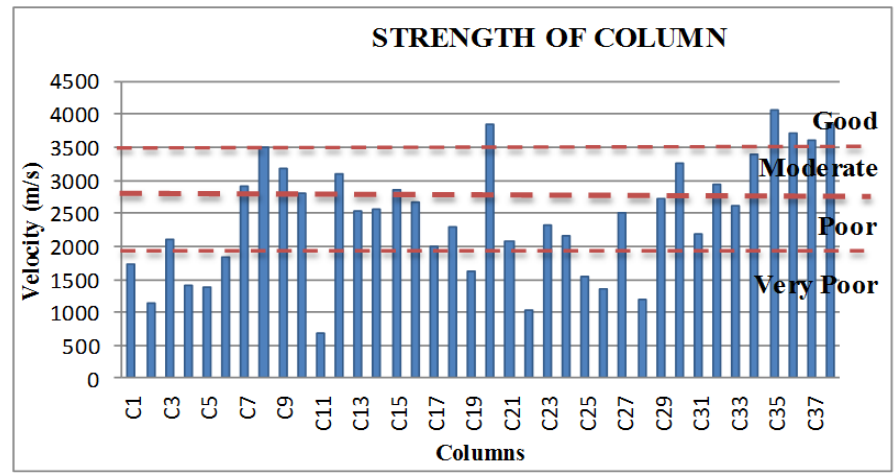

Fig. 12. Test Results PUNDIT for Columns

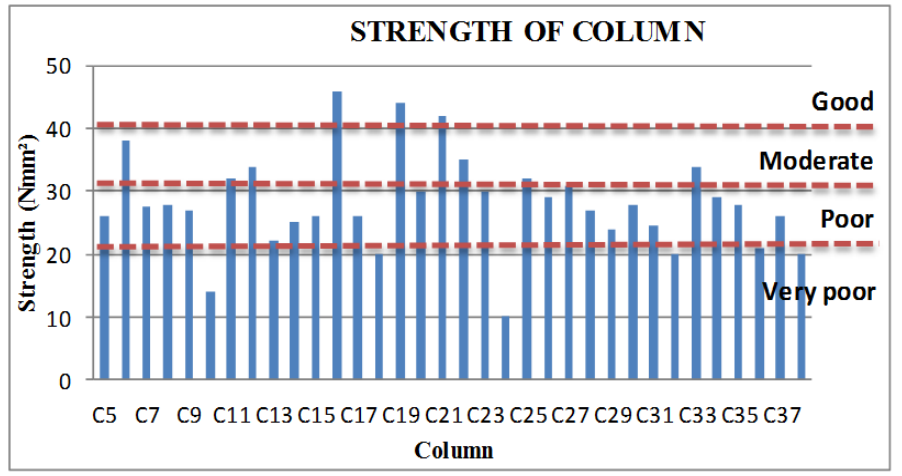

Fig. 13. Schmidt Rebound Hammer test results for columns

Fig. 13 shows the reading of the results of the test hammer Reflection Digischmidt for columns Masjid Haji Muhamad. Based on the graph above, columns C16 had the highest reading of concrete strength of $46 \mathrm{~N} / \mathrm{mm} 2$, followed by columns $\mathrm{C} 19$ and $\mathrm{C} 21$ with a reading of $44 \mathrm{~N} / \mathrm{mm} 2$ and $42 \mathrm{~N} / \mathrm{mm} 2$. As for the strength of concrete is in the range of $40 \mathrm{~N} / \mathrm{mm} 2$ to $30 \mathrm{~N} / \mathrm{mm} 2$, which is at a moderate level is a columns C6, C22, C12, C33, $\mathrm{C} 11, \mathrm{C} 25, \mathrm{C} 27, \mathrm{C} 20$ and $\mathrm{C} 23$. Next to the strength of concrete in between the $30 \mathrm{~N} / \mathrm{mm} 2$ to $20 \mathrm{~N} / \mathrm{mm} 2$ is columns C26, C34, C35, C30, C8, C7, C9, C28, C15, C17, C37, C14, C31, $\mathrm{C} 29, \mathrm{C} 13, \mathrm{C} 36, \mathrm{C} 32, \mathrm{C} 38$ and $\mathrm{C} 18$. Columns have the lowest concrete strength of less than $20 \mathrm{~N} / \mathrm{mm} 2$ is $\mathrm{C} 10$ and $\mathrm{C} 24$.

Fig. 14 shows the results of testing for structural ground beams using PUNDIT testing at Masjid Haji Muhammad. Transmission method was been used in this test is indirect method. The ground beam that having the highest value is B23 which velocity of $2320 \mathrm{~m} /$ $\mathrm{s}$. While the second highest value is B6 velocity of $2123 \mathrm{~m} / \mathrm{s}$. It followed where the velocity readings are within the range of $2000 \mathrm{~m} / \mathrm{s}$ to $1600 \mathrm{~m} / \mathrm{s}$, namely B3, B4, B5, B7, B9, B10, B15, B22, B24, B26 and B29. Next, the readings that obtained between $1500 \mathrm{~m} /$ $\mathrm{s}$ to $1200 \mathrm{~m} / \mathrm{s}$ is B8, B13, B21, and B27. Ground beam which obtained the lowest reading is B12 which is $968 \mathrm{~m} / \mathrm{s}$ and followed by B1 of $913 \mathrm{~m} / \mathrm{s}$ and B17 is $840 \mathrm{~m} / \mathrm{s}$. Finally the lowest reading for low velocity is $\mathrm{B} 16$ which is $780 \mathrm{~m} / \mathrm{s}$.

Fig. 15 shows the readings obtained from Schmidt rebound hammer testing which was conducted on the ground beam at Masjid Haji Muhamad. Based on the results in the graph above, it shows the reading of ground beam for B1 which is the highest concrete strength of $26 \mathrm{~N} / \mathrm{mm}^{2}$ compared with other parts of the ground beam. Ground beam B12 showed the 
second highest concrete strength of $24 \mathrm{~N} / \mathrm{mm}$, followed by B4 and B18. While B3, B5 and $\mathrm{B} 27$ have the same strength of $18 \mathrm{~N} / \mathrm{mm}^{2}$. Similarly of B6, B11 and B21 respectively obtained the concrete strength of $16 \mathrm{~N} / \mathrm{mm}^{2}$. While the ground beam of B2 obtaining concrete strength of $14 \mathrm{~N} / \mathrm{mm}^{2}$. Ground beam that have the lowest strength is B7, B8, B9, $\mathrm{B} 10, \mathrm{~B} 13, \mathrm{~B} 16, \mathrm{~B} 26$ and B28 in which obtained the same strength of $4 \mathrm{~N} / \mathrm{mm}^{2}$. For the ground beam for B17, B22, B19 and B23 each have the strength of $5 \mathrm{~N} / \mathrm{mm} 2$ and $9 \mathrm{~N} /$ $\mathrm{mm}^{2}$. From the graph, the strength of concrete beams for B14, B15, B20, B24 and B25 did not give any concrete strength values.

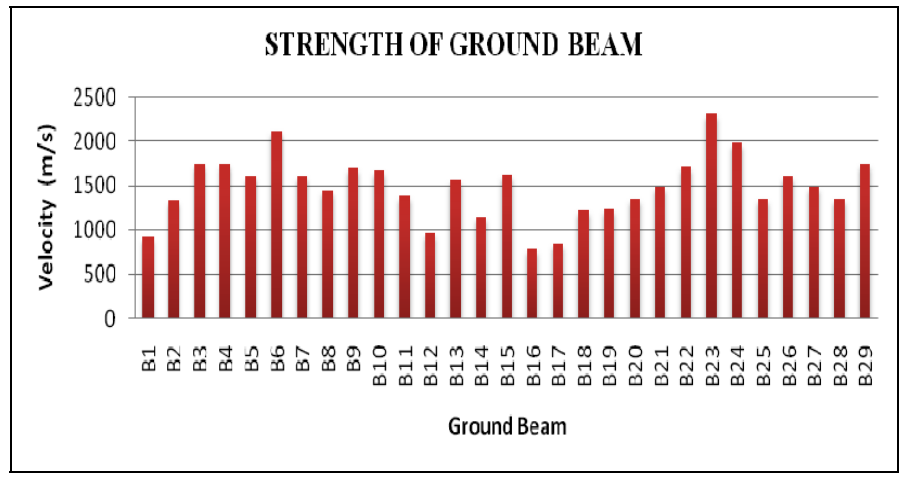

Fig. 14. Test results PUNDIT for ground beams

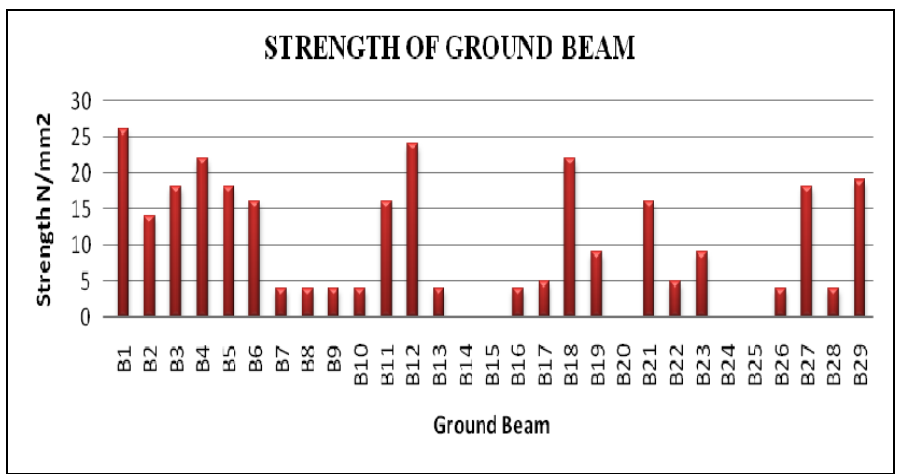

Fig. 15. Schmidt Rebound Hammer Test Results for Ground Beams

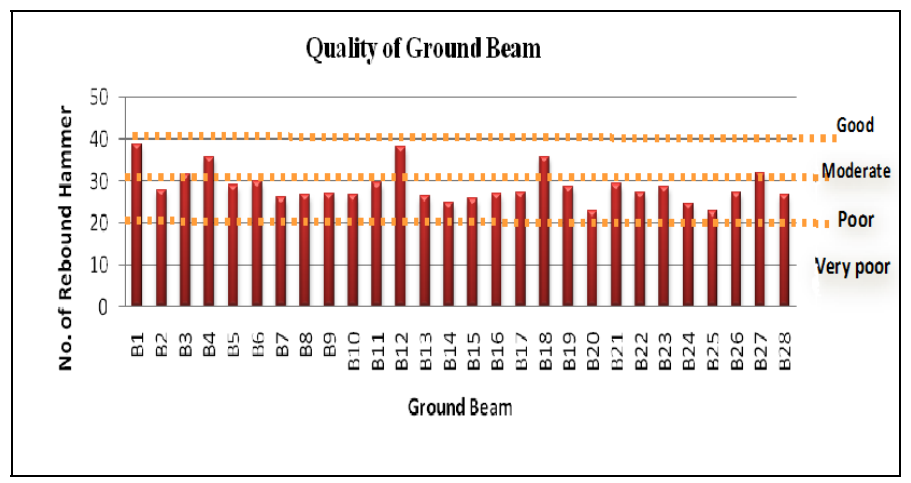

Fig. 16. Schmidt Rebound Hammer test results for quality of ground beams 
The Fig. 16 shows the quality of concrete by Schmidt rebound hammer testing. From the graph, it show the highest number of reflection that is B1, where the quality of the concrete is moderate. While the second highest is the moderate quality of the concrete is B18. Under another beam that has a moderate concrete quality is B3. B4, B6, B12, B21, B27 and B29. For the other beams have a poor quality of concrete.

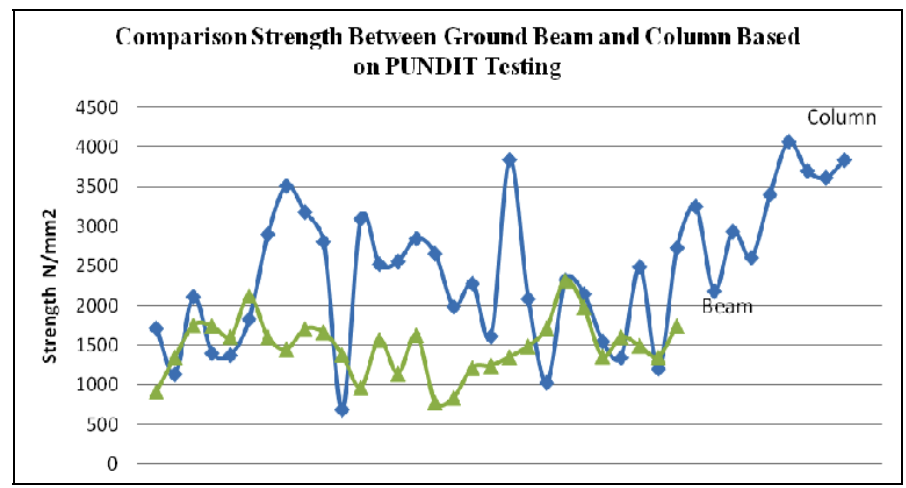

Fig. 17. Comparison strength using PUNDIT testing

According to Fig. 17, it shows the difference of strength for the ground beam and column structures based on PUNDIT testing. From the graph above shows that the structural columns at Masjid Haji Muhammad obtained velocity readings higher than the reading speed of ground beam. Column obtain the highest reading speed which is C20 3840 $\mathrm{m} / \mathrm{s}$ and it provides a good quality concrete, while the lowest recorded reading speed is column C22 of $1030 \mathrm{~m} / \mathrm{s}$ which the quality of the concrete is very weak. For the ground beam, the highest reading obtained velocity is $2320 \mathrm{~m} / \mathrm{s}$. While for the ground beams of B23 and B16 value is the lowest velocity which is $780 \mathrm{~m} / \mathrm{s}$.

Fig. 18 shows the difference in the strength of the structure of columns and ground beam at Masjid Haji Muhamad by using Schmidt rebound hammer testing. Based on the graph (Fig. 18) it to show that the structure of the reading column obtain the high strength compared to strength readings for ground beam structure. The highest reading for the column strength is $46 \mathrm{~N} / \mathrm{mm}^{2}$ for the column $\mathrm{C} 12$. While the lowest strength of the column $\mathrm{C} 20$ is $10 \mathrm{~N} / \mathrm{mm}^{2}$. Compared with the ground beam structure, the highest reading for the strength of concrete is $34 \mathrm{~N} / \mathrm{mm}^{2}$ for B1 and the lowest value of the concrete strength is 4 $\mathrm{N} / \mathrm{mm}^{2}$.

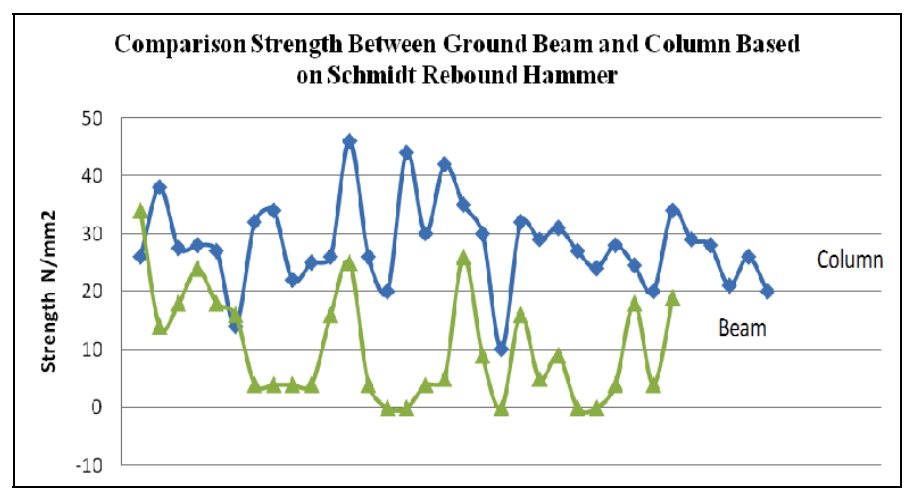

Fig. 18. Comparison strength using Schmidt Rebound Hammer Testing 


\section{Conclusions}

Through testing and data analysis that has been carried out, the conclusion was made based on the test results obtained. This study was conducted to determine the structural strength of wood-based mosque after years of service. Strength level of structure can be determined by using destructive test and non-destructive testing. But for these studies, the selected test is non-destructive testing. This is because these tests can be carried out without disrupting and changing the existing structure. Two methods have been carried out, namely through PUNDIT Test and Schmidt Rebound Hammer. Through both of these tests, data was obtained to determine the structural strength of the Masjid Haji Muhamad. Based on these data, the strength of the structure which are columns and beam are in moderate percentage and weak percentage. Therefore, ongoing review of the appropriate measures for the maintenance and repair needs to be done to ensure the safety of users, so that the mosque will be more permanent.

\section{References}

[1] J. Helal, M sofi, P. Mendis, Non-destructive testing of concrete: A Review of method, Electronic Journal of Structure Engineering, 14(1), 97-105, (2015)

[2] Noor Azreen Masenwat, Kamal Shah Shamsuddin, Mohamad Pauzi Ismail, NDT (Non Destructive Testing) in Civil Engineering: Structural integrity of concrete inspection project, NTC 2011: Nuclear Technical Convention, Malaysia, (2011)

[3] I. Lawson, K.A. Danso, H.C. Odoi, C.A. Adjei, F.K. Quashie, I.I. Mumuni, I.S. Ibrahim, Non-destructive evaluation of concrete using ultrasonic pulse velocity, Research Journal of Applied Sciences, Engineering and Technology 3(6), 499-504, (2011)

[4] M.Z. Rosli, application of non destructive test for structure evaluation, Diss., Universiti Malaysia Pahang, (2010)

[5] N.A.B.M. Pauzi, S. Sani, N. Isa, M.H. Mahmud, Ujian tidak merosakkan (UTMr) terhadap konkrit mengandungi bijih besi, Non destructive Testing (NDT) of concrete Containing Hematite, (2007)

[6] B.R. Jayakumar, T. Thavasimuthu, Practical non-destructive testing, 2nd Eds., Woodhead Publishing Limited, England, (2002)

[7] A.H. Mohammed, W.M. Wan Mat, Teknologi penyenggaraan bangunan, Dewan Bahasa dan Pustaka, Kuala Lumpur, (2002)

[8] K. M. Yusof, Pengenalan kekuatan dan ketahanlasakan konkrit, Dewan Bahasa dan Pustaka, Kuala Lumpur, (1995) 